\title{
KAJIAN EKSTRAK ETANOL MAHKOTA BUNGA KETEPENG CINA (Cassia alata L) SEBAGAI BIOINDIKATOR ASAM BASA
}

\section{[Study of Ethanol Extract of "Ketepeng Cina" (Cassia alata L) Flower Crown as Acid-Base Bioindicator]}

\author{
Khairunnisa $^{1}$, Khairuddin $^{1^{*}}$, Dwi Juli Puspitasari ${ }^{1}$ \\ 1) Jurusan Kimia, Fakultas MIPA, Universitas Tadulako, Palu \\ Jl. Soekarno Hatta Km.9, Kampus Bumi Tadulako Tondo Palu, Telp. 0451- 422611 \\ *)Coresponding author: heru_jns@yahoo.co.id
}

Diterima 12 Juni 2017, Disetujui 21 Oktober 2017

\begin{abstract}
The acid-base bioindicator is an alternative substitute for the synthetic indicator. The study about ethanol extract of Ketepeng Cina crown flowers as an acid-base bioindicator source has been done. The research about utilization of ethanol extract of Ketepeng Cina crown flower was aimed to study compound group, $\mathrm{pH}$ range and acid-base titration which is suitable as bioindicator. This research was performed with gradual extraction by maceration method with three solvents. The results showed that ethanol extract from Ketepeng Cina crown flowers contained flavonoid, polyphenol, alkaloid, and tannin. Extract of Ketepeng Cina crown flower was yellow in acid and orange in the base with the $\mathrm{pH}$ range of 7-9.
\end{abstract}

Keywords : Ketepeng Cina, Bioindicator, Acid-Base, Titration.

\begin{abstract}
ABSTRAK
Bioindikator asam-basa merupakan alternatif utama pengganti indikator sintesis. Ekstrak etanol mahkota bunga Ketepeng Cina (Cassia alata $L$ ) adalah sumber bioindikator asam-basa. Penelitian menggunakan ekstrak etanol mahkota bunga Ketepeng Cina bertujuan untuk mengetahui kelompok senyawa, trayek $\mathrm{pH}$, dan titrasi asam basa yang cocok untuk bioindikator ekstrak etanol mahkota bunga Ketepeng Cina. Pencapaian tujuan dilakukan secara ekstraksi bertingkat dengan metode maserasi dengan tiga jenis pengekstrak (heksan, etil asetat dan etanol). Hasil penelitian menunjukkan ekstrak etanol mengandung kelompok senyawa flaonoid, polifenol, alkaloid dan tannin. Ekstrak mahkota bunga ketepeng cina dalam larutan asam berwarna kuning dan dalam larutan basa berwarna jingga dengan trayek pH antara 7-9. Titrasi asam-basa yang sesuai yaitu titrasi asam kuat- basa kuat dan asam lemah-basa kuat.
\end{abstract}

Kata kunci : Ketepeng Cina, Bioindikator, asam basa, titrasi 


\section{LATAR BELAKANG}

Indonesia merupakan negara tropis yang mempunyai hutan hujan tropis yang kaya dengan keanekaragaman hayati. Tumbuh-tumbuhan telah dimanfaatkan dalam memenuhi kebutuhan hidup manusia sejak dahulu, baik dibidang papan maupun dibidang pangan. Secara etnobotani, masyarakat telah memanfaatkan tumbuhtumbuhan sebagai obat tradisional, racun, pewarna pangan dan non pangan serta pemanfaatan lainnya (Erwin dkk., 2015). Selain itu pemanfaatan tumbuhan adalah sebagai bioindikator asam basa.

Indikator asam basa didefinisikan sebgai senyawa organik yang dapat berubah warna dengan berubahnya derajat keasaman $(\mathrm{pH})$ larutan. Senyawa ini sering digunakan sebagai indikator titik akhir titrasi pada analisis volumetri khususnya metode titrasi asam basa dengan terjadinya perubahan warna pada setiap interval $\mathrm{pH}$. Jenis indikator yang banyak digunakan adalah indicator sintesis, seperti fenolftalein dan metil jingga, tetapi kedua indicator ini mempunyai beberapa kelemahan seperti ketersediaan, polusi kimia, dan biaya produksi mahal. Beberapa penelitian telah dilakukan untuk menggantikan indikator sintesis dengan indikator alami dari berbagai bahan alam.

Bunga dari berbagai jenis tanaman seperti bunga sepatu, bunga rosella dan lain-lain telah digunakan sebagai bioindikator asam basa (Marwati, 2010, Marwati, 2011, dan Marwati, 2012). Ekstrak bunga sepatu dan bunga rosella dapat berperan sebagai bioindikator asam basa (Nuryanti dkk., 2010 dan Nuryanti dkk., 2013). Ekstrak buah dan sayuran telah dilaporkan dapat berperanan sebagai bioindikator (Candra, 2010). Pruetong dkk (2009) melaporkan bahwa ekstrak tanaman dapat dijadikan sebagai bioindikator.

Menurut Shudarshan dkk., (2010), warna bunga tanaman pada umumnya berubah pada daerah $\mathrm{pH}$ tertentu dan mengandung senyawa kelompok flavonoid. Nuryanti dkk., (2010) melaporkan bahwa ekstrak bunga sepatu mengandung senyawa golongan flavonoid, yaitu antosianin jenis pelargonidin yang berubah warna pada daerah $\mathrm{pH}$ tertentu dan dapat digunakan sebagai bioindikator. Ekstraksi zat warna pada tanaman umumnya dilakukan dengan menggunakan metode maserasi (Nuryanti dkk., 2010; Marwati, 2012; Nurbaya, 2015, Kurniawati, 2015)

Ketepeng Cina ( Casiaa alata L) termasuk salah satu jenis tanaman dari famili tumbuhan Fabaceae yang telah dilaporkan mengandung alkaloid, saponin, tannin, steroid, antarkuinon, flavonoid dan katbohidrat dan dimanfaatkan sebagai anti parasit, laksan, kurap, kudis, panu, eksem, malaria, sembelit, radang kulit bertukak, sipilis, herpes, influenza, dan bronchitis (Gama, 2011). Bunga Ketepeng Cina 
berwarna kuning yang mengandung tannin dan flavonoid (Gama, 2011). Sampai saat ini belum ada yang melakukan penelitian dan pemanfaatan ekstrak bunga Ketepeng Cina (Cassia alata L) sebagai bioindikator asam basa, sehingga bunga Ketepeng Cina potensial untuk dimanfaatkan sebagai bioindikator asam basa. Berdasarkan latar belakang di atas, maka perlu dilakukan penelitian untuk mengkaji ekstrak mahkota bunga Ketepeng Cina (Cassia alata L) sebagai bioindikator asam- basa.

\section{BAHAN DAN METODE}

\section{Bahan dan Peralatan}

Bahan dasar yang digunakan dalam penelitian ini adalah mahkota bunga Ketepeng Cina yang diperoleh dari perumahan dosen Universitas Tadulako. Bahan lain mencakup : n-heksan, etil asetat, etanol 96\%, larutan $\mathrm{FeCl}_{3} 5 \%$, $\mathrm{NaOH} 10 \%$, logam Mg, $\mathrm{HCl}$ pekat, pereaksi dragendrof, indikator metil jingga, indikator fenolfthalein, $\mathrm{HCl} 0,1 \mathrm{M}, \mathrm{NaOH} 0,1 \mathrm{M}$, $\mathrm{CH}_{3} \mathrm{COOH} 0,1 \mathrm{M}, \mathrm{NH}_{4} \mathrm{OH} 0,1 \mathrm{M}$, buffer fosfat $\mathrm{pH}$ 1-13, butanol, asam asetat glacial, aquades, iodium, dan plat TLC.

\section{Prosedur Penelitian}

Penelitian dilakukan secara bertahap yang terdiri atas tahap persiapan mahkota bunga Ketepeng Cina, ekstraksi, uji kelompok senyawa dan perubahan warna dalam asam dan basa, penentuan trayek
$\mathrm{pH}$, uji ekstrak pada titrasi asam basa, analisis spectrum UV-VIS dan FTIR.

Tahap persiapan mahkota bunga Ketepeng Cina

Sampel yang digunakan pada penelitian ini yaitu mahkota bunga Ketepeng Cina yang tumbuh di Perumahan dosen UNTAD Kelurahan Tondo, Kecamatan Mantikulore Palu Timur. Mahkota bunga Ketepeng Cina, dibersihkan dan dikeringanginkan hingga kering, setelah itu dihaluskan dengan blender dan diayak dengan ayakan 60 mesh untuk memperoleh tepung mahkota bunga Ketepeng Cina.

\section{Tahap Ekstraksi}

Ekstraksi dilakukan dengan ekstraksi bertingkat menggunakan metode maserasi dengan tiga jenis pelarut. Ekstraksi pertama, digunakan pelarut non polar yakni n-heksan dengan cara menimbang serbuk mahkota bunga Ketepeng Cina sebanyak 25 gram, kemudian dimasukkan ke dalam erlenmeyer $1000 \mathrm{ml}$, selanjutnya ditambahkan 500 ml n-heksan. Campuran diaduk selama 10 menit, setelah itu didiamkan selama 24 jam, kemudian disaring dengan penyaringan vakum. Residu yang diperoleh dikeringanginkan, selanjutnya dimasukkan kedalam erlenmeyer $1000 \mathrm{ml}$, dan ditambahkan etil asetat sebanyak $500 \mathrm{ml}$. Campuran diaduk selama 10 menit setelah itu didiamkan selama 24 jam, kemudian disaring dengan penyaring vakum. Residu yang 
dihasilkan dikeringanginkan, kemudian dimasukkan ke dalam erlenmeyer 1000 ml, dan ditambahkan $500 \mathrm{ml}$ etanol $96 \%$. Campuran diaduk selama 10 menit dan didiamkan selama 24 jam, kemudian disaring dengan penyaring vakum, filtrat yang dihasilkan dipisahkan pelarutnya secara vakum dengan rotary vakum evaporator hingga diperoleh ekstrak pekat dan ditimbang untuk mengetahui rendemennya. Ekstrak etanol dianalisis dengan spektrofotometer UV-Vis dan FT-IR untuk mengetahui jenis gugus fungsi yang ada, selain itu dilakukan uji adanya kelompok senyawa flavonoid, saponin, polifenol, alkaloid dan tannin secara kualitatif.

\section{Tahap uji kelompok senyawa dan perubahan warna dalam asam dan basa}

\section{a. Uji Flavonoid}

Ekstrak etanol mahkota bunga Ketepeng Cina diambil sebanyak $1,0 \mathrm{ml}$, dimasukkan ke dalam tabung reaksi kemudian ditambahkan sedikit serbuk $\mathrm{Mg}$ dan beberapa tetes $\mathrm{HCl}$ pekat (pereaksi Shinoda), bila bereaksi positif, akan menghasilkan larutan berwarna jingga, merah muda atau merah.

\section{b. Uji saponin}

Ekstrak etanol mahkota bunga Ketepeng Cina diambil sebanyak 2,0 ml, dimasukkan ke dalam tabung reaksi kemudian dikocok beberapa menit, bila bereaksi positif akan terbentuk busa yang stabil selama 15 menit.

\section{c. Uji polifenol dan tanin}

Ekstrak etanol mahkota bunga Ketepeng Cina diambil sebanyak $1,0 \mathrm{ml}$, dimasukkan ke dalam tabung reaksi kemudian ditambahkan beberapa tetes larutan $\mathrm{FeCl}_{3} 5 \%$, bila bereaksi positif akan menghasilkan endapan coklat.

\section{d. Uji alkaloid}

Ekstrak etanol mahkota bunga Ketepeng Cina diambil sebanyak $1,0 \mathrm{ml}$, dimasukkan ke dalam tabung reaksi kemudian ditambahkan 2-3 tetes pereaksi Dragendorf, bila bereaksi positif akan menghasilkan endapan jingga.

\section{Uji perubahan warna (uji ekstrak sebagai bioindikator) \\ Asam klorida $0,1 \mathrm{~N}$ dan natrium} hidroksida $0,1 \mathrm{~N}$ diambil dengan pipet ke tabung reaksi, selanjutnya ditambahkan beberapa tetes ekstrak etanol mahkota bunga Ketepeng Cina dan diamati warnanya.

\section{Tahap penentuan trayek $\mathrm{pH}$}

Larutan buffer $\mathrm{pH}$ 1-13 masingmasing 5 tetes dimasukkan dalam plat tetes, kemudian ditambahkan masingmasing 3 tetes ekstrak pekat mahkota bunga Ketepeng Cina 1\% (0,1 g dalam 10 $\mathrm{ml}$ etanol 96\%), kemudian diamati perubahan warna yang terjadi. 


\section{Tahap uji ekstrak pada titrasi asam-basa}

\section{a. Titrasi asam kuat dengan basa kuat}

Larutan $\mathrm{HCl}$ 0,1 $\mathrm{N}$ dipipet sebanyak $10 \mathrm{ml}$, kemudian dimasukkan ke dalam erlenmeyer, selanjutnya ditambahkan 5 tetes ekstrak mahkota bunga Ketepeng Cina. Dititrasi dengan larutan $\mathrm{NaOH} 0,1 \mathrm{~N}$ sampai terjadi perubahan warna. Volume titran yang digunakan dicatat. Titrasi dilakukan sebanyak 3 kali ulangan. Selanjutnya perlakuan ini diulangi dengan mengganti ekstrak mahkota bunga Ketepeng Cina sebagai indikator dengan fenolftalein untuk pembanding.

\section{b. Titrasi asam lemah dengan basa kuat}

Larutan $\mathrm{CH}_{3} \mathrm{COOH} \quad 0,1 \quad \mathrm{~N}$ dipipet sebanyak $10 \mathrm{ml}$, kemudian dimasukkan ke dalam erlenmeyer, selanjutnya ditambahkan beberapa tetes ekstrak mahkota bunga Ketepeng Cina. Dititrasi dengan larutan $\mathrm{NaOH} \quad 0,1 \mathrm{~N}$ hingga terjadi perubahan warna. Volume titran yang digunakan dicatat. Titrasi dilakukan sebanyak 3 kali ulangan. Selanjutnya perlakuan ini diulangi dengan mengganti ekstrak mahkota bunga Ketepeng Cina sebagai indikator dengan fenolfthalein untuk pembanding.

\section{Tahap Pereparasi Uji UV-Vis dan FTIR}

Ekstrak etanol mahkota bunga Ketepeng Cina pekat ditotolkan hingga membentuk pita pada bagian tepi bawah plat TLC, kemudian dikembangkan dengan eluen campuran butanol : asam asetat : air
(4: $1: 5)$ (Ari, 2011). Selanjutnya isolatisolat yang nampak dari pemisahan yang paling baik, ditandai agar memudahkan dalam proses identifikasi. Isolat-isolat tersebut kemudian dikerik, setelah itu dilarutkan dalam etanol $96 \%$. Selanjutnya diukur dengan spektrofotometer UV-Vis dan FTIR, serta diuji warna dengan larutan asam $(\mathrm{HCl} 0,1 \mathrm{M})$ dan larutan basa $(\mathrm{NaOH} 0,1 \mathrm{M})$.

\section{HASIL DAN PEMBAHASAN}

\section{Rendemen dan Kelompok Senyawa Ekstrak Etanol Mahkota Bunga Ketepeng Cina}

Ekstraksi etanol yang dihasilkan dari ekstraksi bertingkat dengan tiga jenis pelarut yang tingkat polaritasnya berbeda (heksana, etil asetat dan etanol) berwarna kuning kecokelatan. Ekstrak pekat kemudian ditimbang, diperoleh 4,666 gram ekstrak. Berdasarkan hal itu, maka diperoleh rendemen ekstrak mahkota bunga Ketepeng Cina sebesar 18,664 \% [(berat ekstrak/berat bunga) x 100\%], yang berarti ekstraksi 100 gram mahkota bunga Ketepeng Cina dihasilkan 18,664 gram ekstrak.

Ekstrak etanol mahkota bunga Ketepeng Cina sangat mungkin mengandung beberapa kelompok senyawa. Untuk mengetahui kelompok senyawa apa yang ada, dilakukan analisis tentang adanya kelompok senyawa alkaloid, flavonoid, saponin, tannin, dan polifenol. 
Hasil yang diperoleh (Tabel 1) menunjukkan ekstrak etanol mahkota bunga Ketepeng Cina mengandung senyawa flavonoid, alkaloid, polifenol, dan tannin.

Tabel 1. Hasil uji kandungan kelompok senyawa ekstrak etanol mahkota bunga Ketepeng Cina

\begin{tabular}{|c|c|c|c|}
\hline No & $\begin{array}{c}\text { Kelompok } \\
\text { senyawa }\end{array}$ & $\begin{array}{c}\text { Hasil } \\
\text { pengamatan }\end{array}$ & Ket. \\
\hline 1 & Flavonoid & $\begin{array}{c}\text { Terdapat } \\
\text { warna jingga }\end{array}$ & + \\
\hline 2 & Saponin & $\begin{array}{c}\text { Tidak terbentuk } \\
\text { buih }\end{array}$ & - \\
\hline 3 & $\begin{array}{l}\text { Polifenol } \\
\text { dan Tanin }\end{array}$ & $\begin{array}{c}\text { Terbentuk } \\
\text { endapan coklat }\end{array}$ & + \\
\hline 4 & Alkaloid & $\begin{array}{c}\text { Terbentuk } \\
\text { endapan jingga }\end{array}$ & + \\
\hline
\end{tabular}

Kelompok Flavonoid dengan struktur molekul dasar (Gambar 1) terdiri atas beberapa bagian, yakni flavon, flavonol, antosianidin, isoflavon, flavanon, dihidroflavonol, biflavonoid, khalkon dan auron (Markham, 1988). Setiap bagian terdiri atas beberapa senyawa, dan nama senyawanya sering diikutkan dengan nama bagian, misalnya antosianidin sianidin (jenis senyawanya sianidin yang masuk kedalam bagian antosianidin). Dengan demikian flavonoid dalam ekstrak etanol mahkota bunga Ketepeng Cina sangat mungkin terdiri lebih dari satu jenis senyawa.

Indikator asam-basa adalah senyawa organik yang merupakan asam ataupun basa lemah yang bentuk tak terurainya dan bentuk ioniknya memiliki warna yang berlainan. Untuk mengetahui apakah senyawa dalam ekstrak etanol mahkota bunga Ketepeng Cina dapat berperanan sebagai indikator, dilakukan uji menggunakan $\mathrm{HCl} 0,1 \mathrm{~N}$ dan $\mathrm{NaOH} 0,1 \mathrm{~N}$. Hasil yang diperoleh menunjukkan ekstrak etanol mahkota bunga Ketepeng Cina dalam larutan asam berwarna kuning dan dalam larutan basa berwarna jingga. Hal tersebut memberikan indikasi ekstrak mahkota bunga Ketepeng Cina dapat berperanan sebagai bioindikator asam basa.

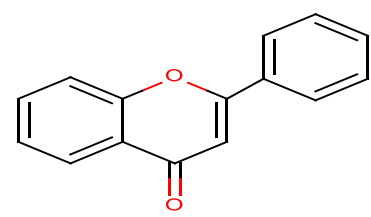

Gambar 1. Struktur dasar kelompok senyawa flavonoid

Spektrum Serapan UV-Vis dan FTIR Ekstrak Etanol Mahkota bunga Ketepeng Cina

Telah diuraikan sebelumnya bahwa ekstrak etanol mahkota bunga Ketepeng Cina mengandung flavonoid yang sangat mungkin terdiri dari satu jenis senyawa. Untuk memprediksi jenis senyawa yang ada, dilakukan analisis spektrum serapan ultra lembayung dan tampak (UV-Vis) serta spektrum FTIR. Hasil analisis spektrum serapan UV-Vis ekstrak mahkota bunga Ketepeng Cina (Gambar 2) terdapat pita serapan optimum pada panjang gelombang $398 \mathrm{~nm}$, berada pada sinar tampak yang 
mencirikan adanya senyawa berwarna. Data serapan tersebut mendukung praduga bahwa ekstrak etanol mahkota bunga Ketepeng Cina tidak mengandung antosianin, sebab senyawa antosianin mempunyai serapan khas pada panjang gelombang antara 465 - $560 \mathrm{~nm}$ (Andersen dan Markham, 2006). Nuryanti (2010) menemukan serapan optimum senyawa antosianin dalam 39 bunga dari spesies Hibiskus adalah $536 \mathrm{~nm}$ dan yang ditemukan dalam mahkota bunga Ketepeng Cina adalah $398 \mathrm{~nm}$.

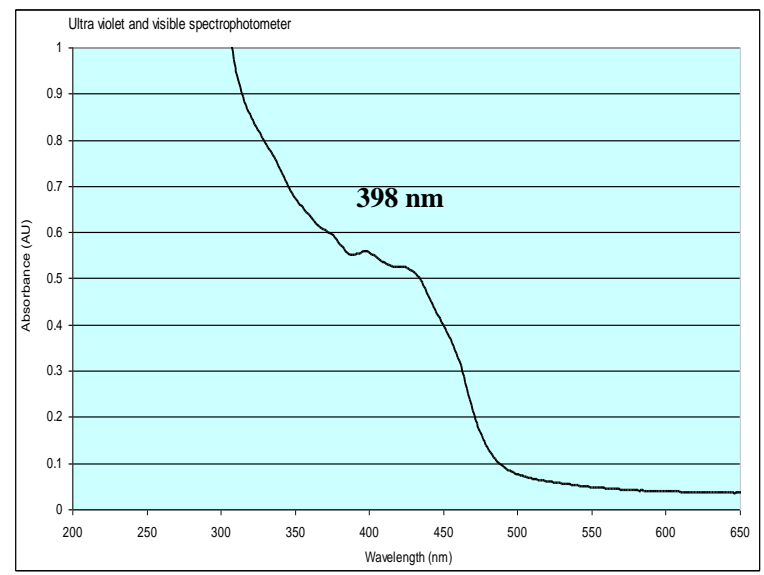

Gambar 2. Spektrum serapan ekstrak mahkota bunga Ketepeng Cina

Menurut Markham (1988), spektrum serapan UV-Vis flavonoid yang khas terdiri atas dua pita maksimal pada rentang 300-560 nm (pita I) dan 230-295 nm (pita II). Rentang spektrum serapan UV-Vis dapat dilihat pada Tabel 2.
Tabel 2. Rentang Serapan Spektrum UVVis Flavonoid (Markham, 1988)

\begin{tabular}{|c|c|c|}
\hline Pita I & Pita II & Jenis Flavonoid \\
\hline $310-350$ & $250-280$ & Flavon \\
\hline $330-360$ & $250-280$ & $\begin{array}{l}\text { Flavonol (3-OH } \\
\text { tersubsitusi) }\end{array}$ \\
\hline $350-385$ & $250-280$ & $\begin{array}{l}\text { Flavonol }(3-\mathrm{OH} \\
\text { bebas) }\end{array}$ \\
\hline $310-330$ & $245-275$ & Isoflavon \\
\hline $\begin{array}{c}\text { Kira-kira } \\
320 \\
\text { puncak }\end{array}$ & & $\begin{array}{l}\text { Isoflavon (5-deoksi- } \\
\text { dioksigenasi) }\end{array}$ \\
\hline $300-330$ & $275-295$ & $\begin{array}{l}\text { Flavonon dan } \\
\text { dihidro flavonol }\end{array}$ \\
\hline $340-390$ & $230-270$ & Khalkon \\
\hline $380-430$ & $230-270$ & Auron \\
\hline $465-560$ & $270-280$ & $\begin{array}{l}\text { Antosianidin dan } \\
\text { antosianin }\end{array}$ \\
\hline
\end{tabular}

Pada tabel tersebut memperlihatkan rentang serapan flavonoid yang ada di daerah sekitar $398 \mathrm{~nm}$ adalah golongan senyawa flavonoid jenis auron, sehingga terdapat dugaan ekstrak mahkota bunga Ketepeng Cina mengandung satu jenis golongan senyawa flavonoid tersebut. Struktur molekul golongan senyawa flavonoid jenis auron dapat dilihat pada Gambar 3.

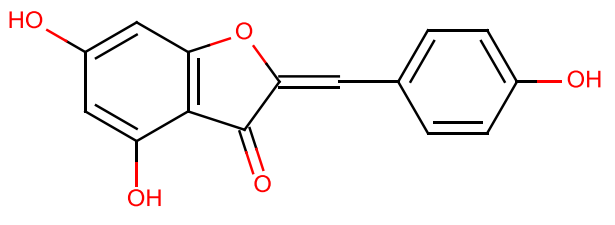

Auron

Gambar 3. Struktur molekul Auron

Hasil pengambilan spektrum FTIR (Gambar 4) memperlihatkan terdapat 
puncak absorpsi atau pita absorpsi di daerah bilangan gelombang lebih kecil dari $1400 \mathrm{~cm}^{-1}$ yang disebut daerah sidik jari (fingerprint region) dan didaerah panjang gelombang gugus fungsi (daerah panjang gelombang antara 1400 dan $4000 \mathrm{~cm}^{-1}$ ). Pita adsorpsi yang muncul terdiri atas pita yang kuat, medium dan pita adsorpsi yang lemah serta pita bahu. Pita kuat ditemukan pada bilangan gelombang 3379,29; 1720,$50 ; 1382,96 ; 1060,85 ; 669,30$ dan $619,15 \mathrm{~cm}^{-1}$; pita sedang ditemukan pada bilangan gelombang 1633,71 dan 1259,52 $\mathrm{cm}^{-1}$; pita lemah terdapat pada bilangan gelombang 867,97; 817,82 dan $777,31 \mathrm{~cm}^{-}$ 1, dan pita bahu terdapat pada bilangan gelombang $2927,94 \mathrm{~cm}^{-1}$.

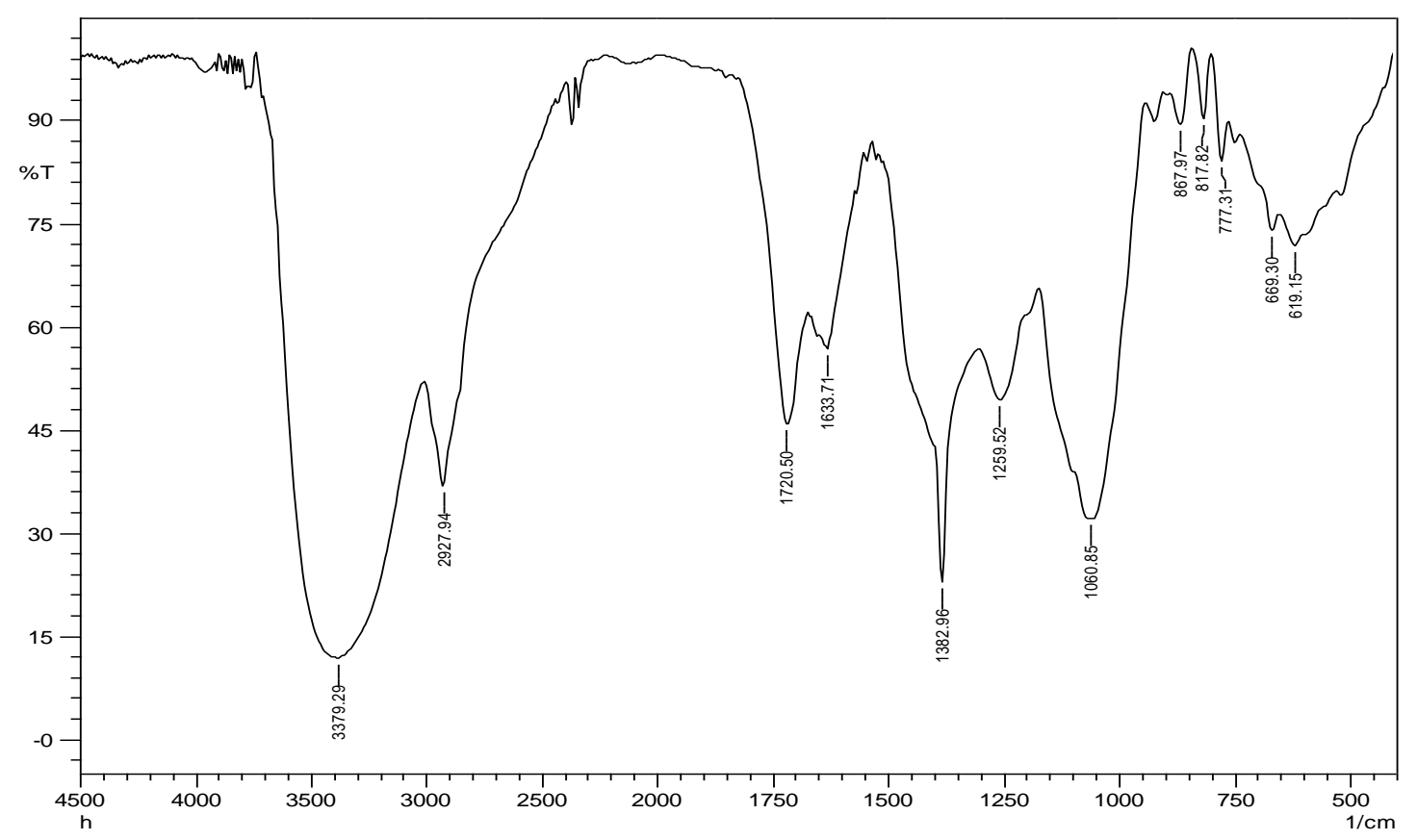

Gambar 4. Hasil pengukuran spektrum FTIR ekstrak mahkota bunga Ketepeng Cina

Serapan lebar pada bilangan gelombang $3379,29 \mathrm{~cm}^{-1}$ merupakan pita serapan khas ikatan hidrogen $(-\mathrm{OH})$ yang berarti terdapat gugus hidroksil yang dapat melakukan ikatan hidrogen. Adanya serapan yang kuat pada bilangan gelombang 1720,50 $\mathrm{cm}^{-1}$ dapat diperkirakan sebagai pita serapan senyawa Oheterosiklik yang terkonyugasi dengan cincin benzena (Qin, dkk., 2010). Menurut
Nuryanti dkk., (2013) pita serapan disekitar $1630 \mathrm{~cm}^{-1}$ merupakan vibrasi stretching ikatan C - O - C pada cincin pirilium yang berkonyugasi dengan ikatan ganda karbonkarbon $(\mathrm{C}=\mathrm{C})$.

Dugaan golongan senyawa flavonoid jenis auron dari ekstrak juga didukung oleh data spectrum inframerah ekstrak mahkota bunga Ketepeng Cina yang menunjukan adanya serapan $\quad-\mathrm{OH}$ pada daerah 
bilangan gelombang $3379,29 \mathrm{~cm}^{-1}$; gugus $\mathrm{C}=\mathrm{O}$ pada $1720,50 \mathrm{~cm}^{-1}$ dan gugus C-O-C- pada $1060,85 \mathrm{~cm}^{-1}$. Keterangan lebih lengkap dapat dilihat pada Tabel 3.

Tabel 3. Interpretasi Spektrum FTIR Ekstrak Mahkota Bunga Ketepeng Cina

\begin{tabular}{|c|c|c|c|}
\hline \multicolumn{2}{|c|}{$\begin{array}{c}\text { Bilangan } \\
\text { Gelombang } \\
\left(\mathrm{cm}^{-1}\right)\end{array}$} & \multirow{2}{*}{$\begin{array}{c}\text { Bentuk } \\
\text { Pita }\end{array}$} & \multirow{2}{*}{ Keterangan } \\
\hline $\begin{array}{l}\text { Auron } \\
\left(\mathrm{cm}^{-1}\right)\end{array}$ & $\begin{array}{c}\text { Pustaka } \\
\text { Pavia } \\
\text { (2009) }\end{array}$ & & \\
\hline $\begin{array}{l}3379, \\
29\end{array}$ & $\begin{array}{l}3400- \\
3200\end{array}$ & Melebar & $\begin{array}{l}-\mathrm{OH} \\
\mathrm{H}-\text {-bonded }\end{array}$ \\
\hline $\begin{array}{l}2927, \\
94\end{array}$ & $\begin{array}{l}3000- \\
2840\end{array}$ & Tajam & $\mathrm{C}-\mathrm{H} \mathrm{sp}^{2}$ stretch \\
\hline $\begin{array}{l}1720 \\
50\end{array}$ & $\begin{array}{l}1725- \\
1705\end{array}$ & Tajam & $\mathrm{C}=\mathrm{O}$ Stretch \\
\hline $\begin{array}{l}1633 \\
71\end{array}$ & $\begin{array}{l}1680- \\
1600\end{array}$ & Tajam & $-C=C-$ stretch \\
\hline $\begin{array}{l}1382, \\
96\end{array}$ & 1375 & Tajam & $\mathrm{C}-\mathrm{H}$ bend \\
\hline $\begin{array}{l}1060 \\
85\end{array}$ & $\begin{array}{l}1300- \\
1000\end{array}$ & Tajam & $\begin{array}{l}-\mathrm{C}-\mathrm{O}-\mathrm{C}- \\
\text { stretch }\end{array}$ \\
\hline
\end{tabular}

\section{Daerah pH Ekstrak Etanol Mahkota Bunga Ketepeng Cina}

Untuk memprediksi daerah $\mathrm{pH}$ ekstrak mahkota bunga Ketepeng Cina, dilakukan analisis perubahan warna menggunakan buffer fosfat $\mathrm{pH} 1$ sampai pH 13. Hasil yang diperoleh (Gambar 5) , menunjukkan bahwa $\mathrm{pH}$ 1-6 larutan berwarna kuning, $\mathrm{pH}$ 7 berwarna jingga muda, diatas $\mathrm{pH} 7$ larutan berwarna jingga.

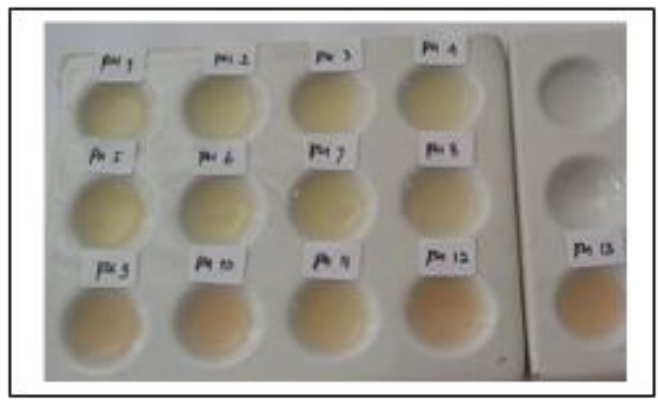

Gambar 5. Perubahan warna ekstrak mahkota bunga Ketepeng Cina dalam larutan buffer posfat $\mathrm{pH}$ $1-13$

\section{Ekstrak Mahkota Bunga Ketepeng Cina Sebagai Indikator Titrasi Asam- Basa}

Hasil titrasi asam kuat basa kuat dengan menggunakan ekstrak mahkota bunga Ketepeng Cina, terlihat titik ekivalen tercapai pada saat penambahan volume $11,13 \mathrm{ml} \mathrm{pH} \mathrm{8,80} \mathrm{dengan} \mathrm{perubahan} \mathrm{warna}$ dari kuning menjadi jingga. Sedangkan untuk titrasi asam basa dengan indikator fenolftalein yang digunakan sebagai pembanding, titik ekivalen tercapai pada penambahan volume titran $10,96 \mathrm{ml}$ dengan $\mathrm{pH} 8,43$ dengan perubahan warna dari tak berwarna menjadi merah muda. Secara teori rentang $\mathrm{pH}$ perubahan indikator fenolftalein berada pada kisaran 8,0-9,6 (Day dan Underwood, 2002), sehingga rentang $\mathrm{pH}$ perubahan warna ekstrak mahkota bunga Ketepeng Cina masih berada pada range perubahan $\mathrm{pH}$ indikator fenolftalen.

Hasil titrasi asam lemah - basa kuat dengan menggunakan indikator ekstrak mahkota bunga Ketepeng Cina dengan pembanding indikator fenolftalein, terlihat 
bahwa ada kesamaan antara hasil titrasi asam kuat dan basa kuat, dengan asam lemah dan basa kuat. Titik ekivalen juga tercapai pada kisaran volume penambahan titran $\mathrm{NaOH}$ sekitar 11,13 $\mathrm{ml}$ dan $\mathrm{pH} 8,84$ dengan perubahan warna dari kuning menjadi jingga untuk indikator ekstrak mahkota bunga Ketepeng Cina, dan 10,93 $\mathrm{ml}$ dan $\mathrm{pH} 8,46$ dengan perubahan warna dari tak berwarna menjadi merah muda untuk indikator fenolftalein. Dari kedua perlakuan titrasi di atas nampak terlihat bahwa ekstrak mahkota bunga Ketepeng Cina yang digunakan sebagai indikator hampir sama penambahan volume titran $\mathrm{NaOH}$ dengan indikator fenolftalein.

Berdasarkan hasil titrasi dapat diasumsikan bahwa ekstrak etanol mahkota bunga Ketepeng Cina dapat digunakan sebagai indikator dalam titrasi asam basa yaitu sebagai pengganti indikator fenolftalein pada titrasi asam kuat basa kuat, asam lemah basa kuat. Nuryanti dkk., (2010) menemukan ekstrak bunga Sepatu dapat berperanan sebagai indikator untuk titrasi asam kuat dengan basa kuat, asam lemah dengan basa kuat serta titrasi asam kuat dengan basa lemah. Dalam ekstrak bunga Sepatu teridentifikasi mengandung antosianin yang berperanan sebagai indikator asam-basa. Hasil uji ekstrak mahkota bunga Ketepeng Cina sebagai indikator memperkuat praduga bahwa golongan senyawa flavonoid yang terdapat pada ekstrak mahkota bunga Ketepeng Cina adalah jenis senyawa auron.

\section{KESIMPULAN}

Berdasarkan hasil penelitian dapat disimpulkan bahwa ekstrak etanol mahkota bunga Ketepeng Cina (Cassia alata L) mengandung senyawa flavonoid, alkaloid, polifenol dan tannin serta serapan maksimum ekstrak etanol mahkota bunga Ketepeng Cina berada pada 398 nm yang menunjukkan golongan senyawa flavonoid jenis auron. Trayek pH pada ekstrak etanol mahkota bunga Ketepeng Cina (Casssia alata L) adalah pada daerah $\mathrm{pH} 7$ hingga pH 9. Ekstrak etanol mahkota bunga Ketepeng Cina (Casssia alata L) dapat dijadikan sebagai indikator alami titrasi asam basa yakni pada titrasi asam kuatbasa kuat dan titrasi asam lemah-basa kuat, tetapi tidak dapat digunakan pada titrasi asam kuat basa lemah.

\section{DAFTAR PUSTAKA}

Ari, I Gusti Ketut 2011. Analisis senyawa golongan flavonoid esktrak metanol biji buah rambutan (Nephelium lappaceum L.). (Skripsi). Palu: Universitas Tadulako.

Candra, A. A. S. 2010. Karakterisasi Trayek $\mathrm{pH}$ dan Spektrum Absopsi Ekstrak Kubis Ungu Kering (Brassica oleracea) sebagai Indikator Alami Titrasi Asam Basa. Laporan Penelitian. Yogyakarta: FMIPA UNY.

Erwin, Muhammad, A.N., A. Sentosa, P. 2015. Potensi Pemamfaatan Ekstrak Kubis Ungu (Brassica oleracea) 
sebagai Indikator Asam Basa Alami. Jurnal Kimia Mulawarman, 13(1).

Gama AMP. 2011. Perbandingan Ekstrak Daun Ketepeng Cina (Cassia alata L.) dengan Ketokonazol $2 \%$ dalam Menghambat Pertumbuhan Malassezia Fulfur pada Pityriasis Versicolor secara In Vitro. (Skripsi). Semarang: Fakultas Kedokteran UNDIP.

Kurniawati, 2015. Kajian Ekstrak Etanol Bunga Tanaman Johar (Cassia siamea L) sebagai Bioindikator Asam Basa, Skripsi. Palu: Jurusan Kimia FMIPA UNTAD.

Markham K.R. 1988. Techniques of Flavonoids Identification, diterjemahkan oleh Kosasih Padmawinata, Bandung: Penerbit ITB.

Marwati S. 2010. Aplikasi Beberapa Ektrak Bunga Berwarna sebagai Indikator Alami Titrasi Asam Basa, Prosiding Seminar Nasional Penelitian, Pendidikan dan Penerapan MIPA FMIPA UNY, 15 Mei 2010.

Marwati S, 2011, KestAabilan warna Ekstrak Kubis Ungu (Brassica oleracea) sebagai Indikator alami Titrasi Asam Basa. Prosiding Seminar Nasional Penelitian, Pendidikan dan Penerapan MIPA. FMIPA UNY, 11 Mei 2011.

Marwati S, 2012, Ekstraksi dan Preparasi Zat Warna Alami sebagai Indikator Alami Titrasi Asam Basa. Prosiding Seminar Nasional Penelitian, Pendidikan dan Penerapan MIPA. FMIPA UNY, 02 Juni 2012.

Nurbaya, 2015. Kajian Ekstrak Etanol Bunga Kembang Telang (Clitoria ternate) sebagai Bioindikator Asam
Basa, (Skripsi). Palu: Jurusan Kimia FKIP UNTAD.

Nuryanti, S. Matsjeh, Chairil Anwar, Tri Joko Raharjo. 2010. Indikator Titrasi AsamBasa Dari Ekstrak Bunga Sepatu (Hibiscus rosa sinensis L). AGRITECH, 30(3): 178-183.

Nuryanti, S; S. Matsjeh; C. Anwar; T.J. Raharjo dan B. Hamzah. 2013. Corolla Of Roselle (Hibiscus Sabdariffa $L$ ) as Acid-Base Indikator. Eurjchem, 4(1): 20-24.

Pavia, D., G.M. Lampman., G.S Kriz., J.R Vyvyan. 2009. Introduction To Spectroskcopyl. Fourth Edition. Departement of Chemistry. Bellingham Washington: Westren Washington University.

Pruetong, S., Saijeen, S., Thongfak, K. 2009. Study and Processing of Plant Extracts for Use as $\mathrm{pH}$ Indicators. International Conference on the Role of Universities in Hands-On Education Rajamangala University of Technology Lanna, Chiang-Mai, Thailand 23-29 August 2009.

Qin, C., Ly., Niu, W., Ding, Y., Zhang, R., dan Shang, S. 2010. Analysis and characterization of anthocyanidins in mulberry fruit. Journal of Food Science, 28(2): 117-128.

Day R.A. \& A.L. Underwood, 1999. SAnalisis Kimia Kuantitatif. Jakarta: Erlangga.

Shudarshan, S., Bothara, S.B., Sangeeta, S., Roshan, P., Naveen, M. 2010. Pharmaceutical Character of Flower as Natural Indicator: Acid-Base. A Journal The Pharma Research, . 4:83-90. 